\title{
Ultrastructure of the Corpuscular Nerve Ending in the Lymph Heart of the Turtle (Pseudemys scripta elegans)
}

\author{
Yoh-ichi SATOH ${ }^{1}$ and Tohru NITATORI ${ }^{2}$ \\ Department of Anatomy (Prof. K. ONo), ${ }^{1}$ Asahikawa Medical College, Asahikawa, and Department of \\ Anatomy (Prof. C. IDE), ${ }^{2}$ Iwate Medical University School of Medicine, Morioka, Japan
}

Received May 13, 1982

Summary. Corpuscular nerve endings were found in the tunica externa of the lymph heart of a turtle (Pseudemys scripta elegans). They consisted of axon terminals and surrounding cellular lamellae. Serial thin sections of one such presumable sensory corpuscle were made and reconstructed for the three-dimensional analysis of the corpuscle, with special reference to the axon terminals. It was revealed that axon terminals ramified at several points within the corpuscle and formed varicosities of various sizes ranging from 1.0 to $3.0 \mu \mathrm{m}$ in diameter in their courses. Such varicosities contained an abundance of mitochondria as well as clear and granular vesicles 500 to $800 \AA$ in diameter. Finger-like protrusions of ten projected from the axon terminals into the interlamellar spaces. The lamellae consisted of several thin cytoplasmic processes of modified Schwann cells. The corpuscle was enclosed in an incomplete capsule consisting of a thin layer of cellular processes. The corpuscular nerve endings may represent pressoreceptors in the wall of the lymph heart.

The lymph heart is a pulsating chamber located at the sites where lymph vessels enter the veins. This occurs in many classes of vertebrates, except mammalia. There have been many light (see review by KAMPMEIER, 1969) and electron microscopic studies (Kawaguti, 1967; Rumyantsev and Shmantzar, 1967; Schipp and Flindt, 1968; Lindner and Schaumburg, 1968; SATOH and NitATORI, 1980) on the structure and on the development of the lymph heart. As most of these studies are on the muscle fibers and their motor innervations, available reports on the sensory innervation of the lymph heart are quite limited in number. ITO (1944) observed Meissner-like corpuscles on the wall of the lymph heart of turtles and snakes by means of a silver impregnation method. SATOH and NitATORI (1980) observed corpuscular nerve endings consisting of axon terminals intimately surrounded by multiple-stacked lamellae in the tunica externa of the turtle lymph heart. These lamellated corpuscles were thought to represent pressoreceptors in the lymph heart. No report has been available on the detailed descriptions of the ultrastructure of such pressoreceptors.

In this study, a three-dimensional analysis was performed in one such lamellated corpuscle by reconstruction of serial thin sections for electron microscopy. Special reference was given to the ramification pattern and the varicosity formation of the axon terminals within the corpuscle. 


\section{MATERIALS AND METHODS}

Red-eared turtles (Pseudemys scripta elegans), 4-5 g in body weight, were used in this study. After they were chilled in ice-cold water to an anesthetic state, the caudal part of the carapace was removed, and the pulsating posterior lymph heart was immediately excised and fixed by immersion for a few minutes in an ice-cold fixative containing $1.25 \%$ glutaraldehyde and $4 \%$ paraformaldehyde in 1/15 M phosphate buffer $(\mathrm{pH} 7.4)$. The specimens were then postfixed in a $1 \%$ osmium tetroxide solution in the same buffer for $90 \mathrm{~min}$. After a brief washing in the buffer, the specimens were dehydrated through a graded ethanol series and embedded in Epon 812 through n-butyl glycidyl

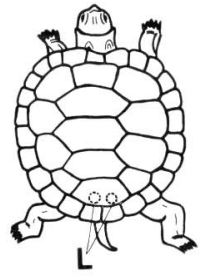

a

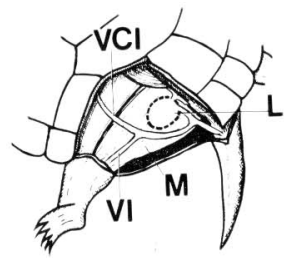

b

Fig. 1. Diagram of the Pseudemys, showing the site of the lymph heart. a. The small rings indicate the position of two posterior lymph hearts $(L)$. b. Part of the scales covering the lymph heart was removed. The lymph heart $(L)$ lies on the posterior limb muscles $(M)$, and pumps the lymph into the vein which is a branch of the vena circumflexa ileum (VCI), receiving vena ischiadica (VI). schematic drawing of the lamellated corpuscle was made with three-dimensional visualization (Fig. 9).

\section{RESULTS}

The two posterior lymph hearts of the turtle are located in the connective tissue just below the rear-most large median plate of the carapace resting on the muscles of each posterior limb (Fig. la, b). These lymph hearts pour lymph into the branches of the vena circumflexa ileum, which flows into the vena portae renalis.

Though the wall of the Pseudemys lymph heart is very thin and transparent, it consists of three tunicae, as observed by electron microscopy: 1) tunica intima, composed of a continuous layer of endothelial cells and supporting connective tissue, 2) tunica media, consisting of slender striated muscle fibers, with a few peripherally located nuclei, and 3) tunica externa, containing fibroelastic tissue penetrated by blood vessels. A group of lamellated corpuscles was observed in the tunica externa (Fig. 2), measuring about $50 \mu \mathrm{m}$ in length and about $20 \mu \mathrm{m}$ in width. These lamellated corpuscles were situated with the long axis oriented almost obliquely in the direction of the lymph heart. The lamellated corpuscles consisted of ramified axon terminals and the surrounding multiple-stacked lamellae. Thin cellular processes formed an incomplete sheath or a capsule around these lamellated corpuscles. 


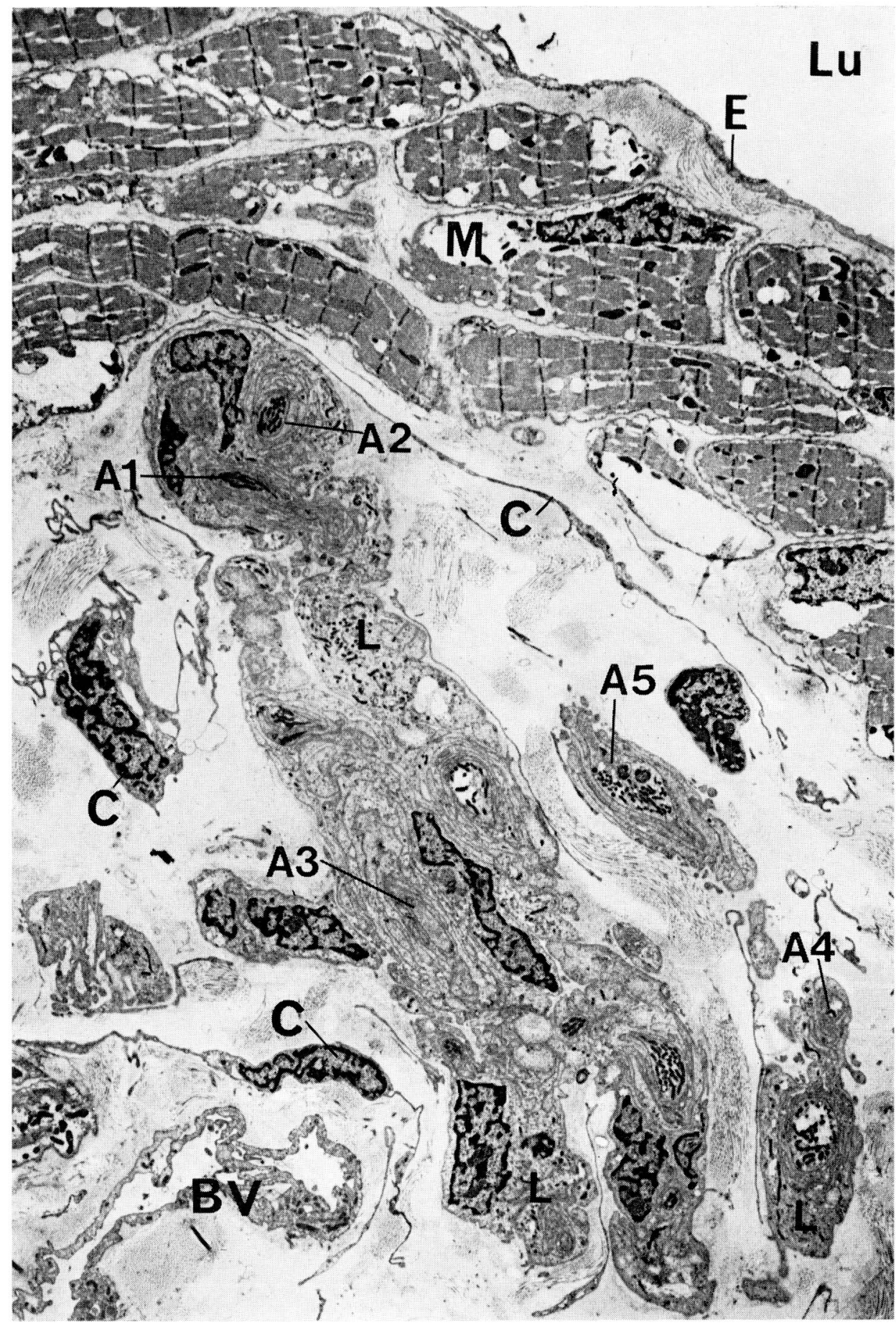

Fig. 2. Low electron micrograph showing the wall of a Pseudemys lymph heart. Lamellated corpuscles exist in the fibroelastic tunica externa of the lymph heart. A 1-5 nerve fibers surrounded by multiple-stacked lamellae $(L), C$ capsule of lamellated corpuscle, $L u$ lumen of the lymph heart, $E$ endothelium of the lymph heart, $M$ striated muscle fibers in the tunica media, $B V$ blood vessel. The serial sectioning started at this level. $\times 1,900$ 


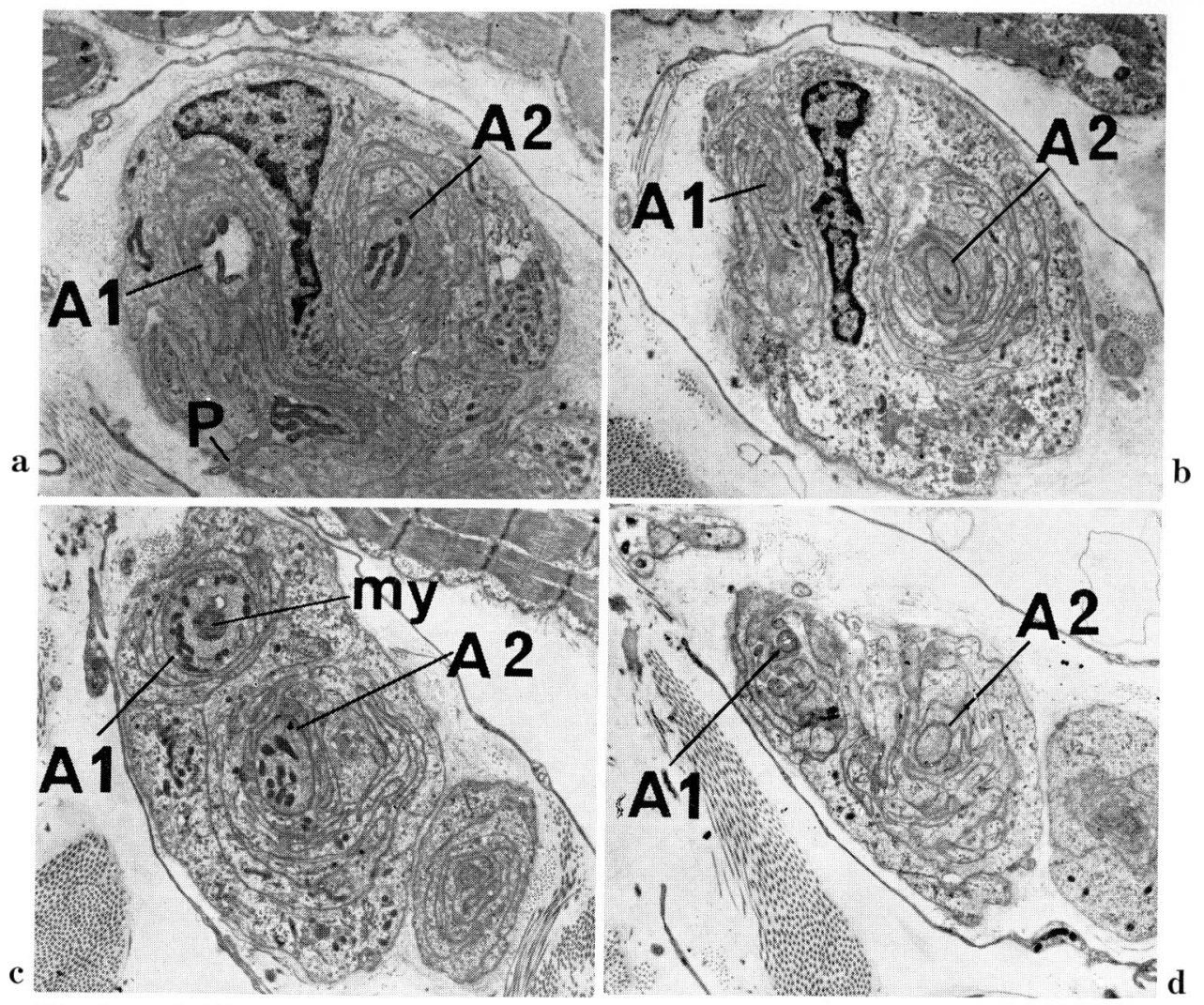

Fig. 3. a-d. Electron micrographs of consecutive serial sections showing the two axon terminals, $A 1$ and $A 2$ in Figure 2. About $0.9 \mu \mathrm{m}$ interval exists between Figures 2 and $3 \mathrm{a}$, about $2.7 \mu \mathrm{m}$ between Figures $3 \mathrm{a}$ and $3 \mathrm{~b}$, about $3.8 \mu \mathrm{m}$ between Figures $3 \mathrm{~b}$ and $3 \mathrm{c}$, and $2.8 \mu \mathrm{m}$ between Figures $3 \mathrm{c}$ and $3 \mathrm{~d}$. It is evident that both axon terminals have two enlargements within each $10 \mu \mathrm{m}$ length of their axon courses. my Myelin-figure body, $P$ finger-like protrusion of the $A 1$ axon terminal. $\times 6,500$

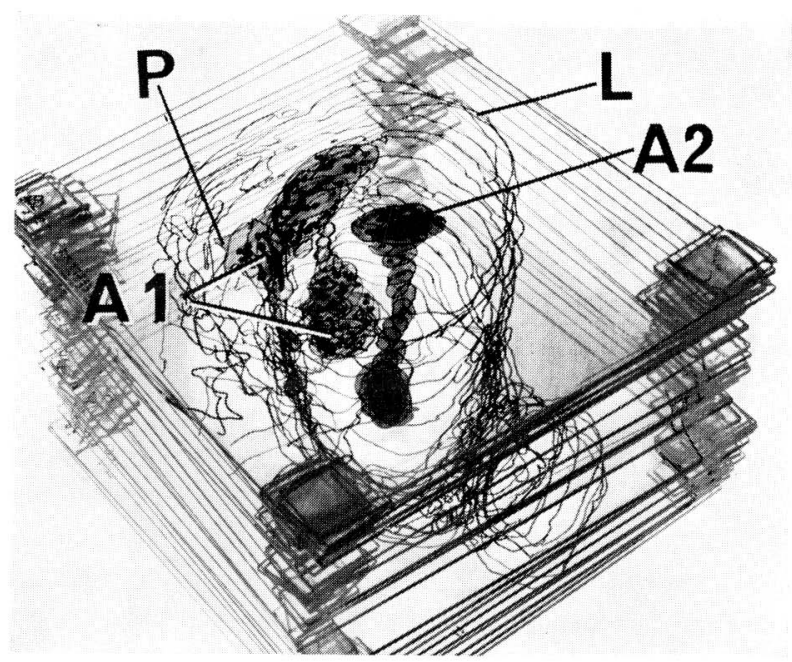

Fig. 4. The reconstruction of the axon terminal of $A 1$ and $A 2$ shown in Figure 3. The electron micrographic images were drawn on acrylic sheets by selecting one out of every 5 micrographs, thus obtaining 20 drawings from 100 micrographs of serial thin $(0.1 \mu \mathrm{m}$ thick $)$ sections. Accordingly the gap between adjacent acrylic sheets represents about $0.5 \mu \mathrm{m}$ of the actual depth. $L$ profile of the outermost lamella, $P$ fingerlike protrusion of the $A 1$. 
a
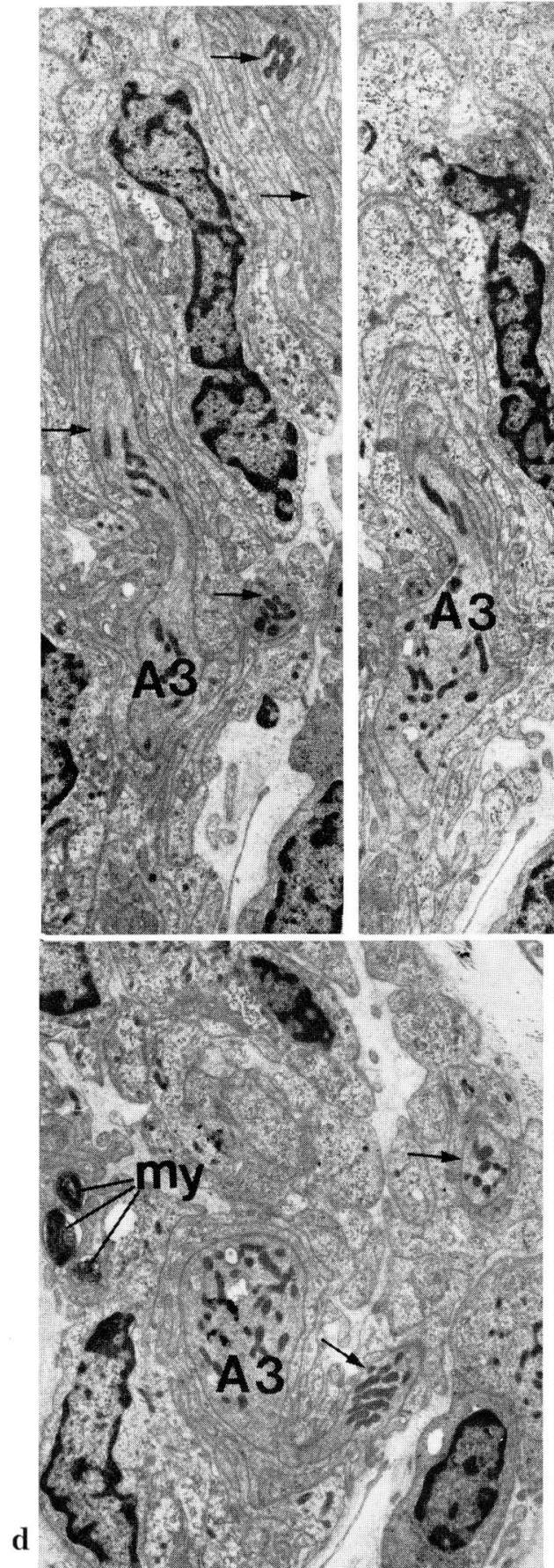

b

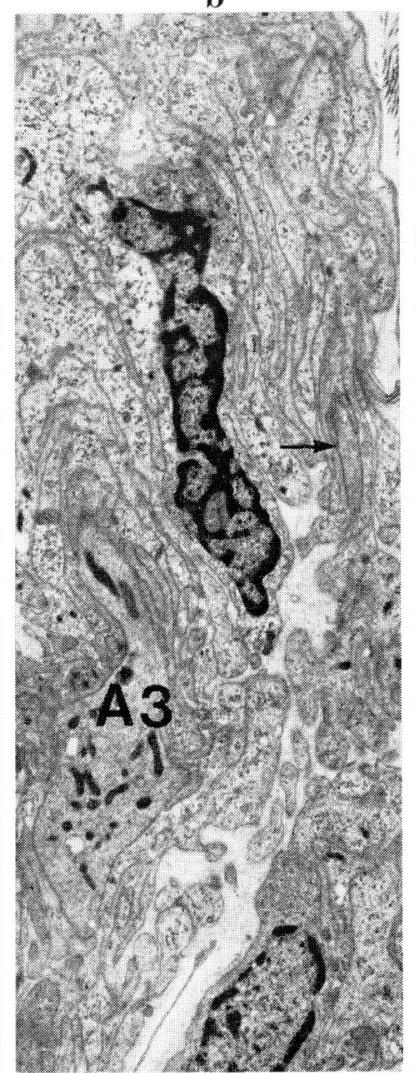

c

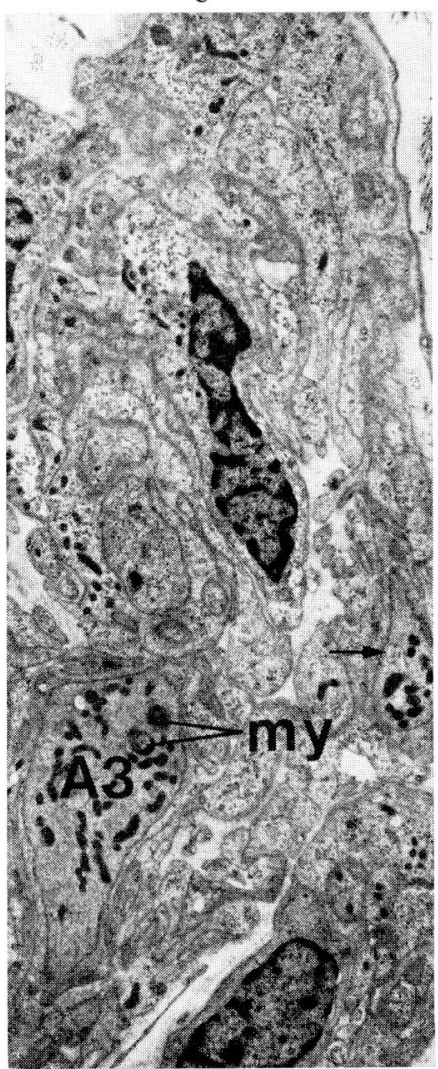

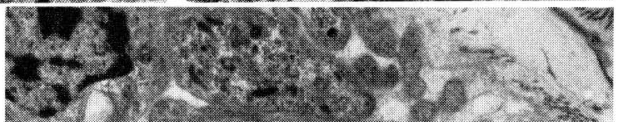

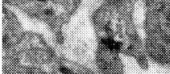

(4) (2)

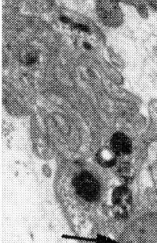

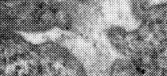

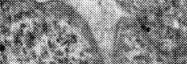

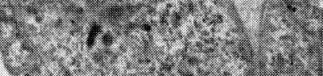

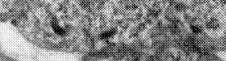
2.
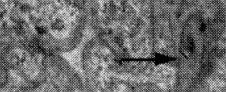

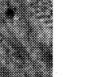


The axon terminals branched out and were repeatedly swollen within the corpuscle (Fig. 3a-d, 4, 5a-e, 9). Based on the reconstruction of the serial sections, several varicosities of 1.0 to $3.0 \mu \mathrm{m}$ in diameter and containing many mitochondria and glycogen granules (Fig. 6,7), were observed in the axon leading to the axon terminal. Myelinfigure bodies and multivesicular bodies were also found in the central region of the varicosities (Fig. 3c, 5c). Neurofilaments and neurotubules were less numerous. In a few cases, parts of the swollen axon terminals were not covered by lamellae (Fig. 5e). Such parts were covered only by a basal lamina. A cluster of clear vesicles (about $500 \mathrm{~A}$ in diameter) was found in the periphery of the varicosities (Fig. 6, 7). Granular vesicles (about $800 \AA$ in diameter) were rare.

Small finger-like protrusions (about $0.4 \mu \mathrm{m}$ in diameter and about $1.0 \mu \mathrm{m}$ in length) extended from the axon terminals and penetrated into spaces between the lamellae (Fig. 3a, 7). The protrusions contained longitudinally-oriented microfilaments and occasional clear vesicles of about $500 \AA$ in diameter. Some of the protrusions extended through the stack of lamellae to the connective tissue. The basal lamina on such protrusions was obscure.

The axon terminals were intimately surrounded by about three to ten layers of cytoplasmic processes (lamellae) of lamellar cells. The gap between the axon terminal and the inner-most lamella measured $170 \AA$, and desmosome-like junctions were recognized between these two elements (Fig. 6,7). The outermost lamella was thicker than the inner lamellae and contained a nucleus with a conspicuous nucleolus. Mitochondria,

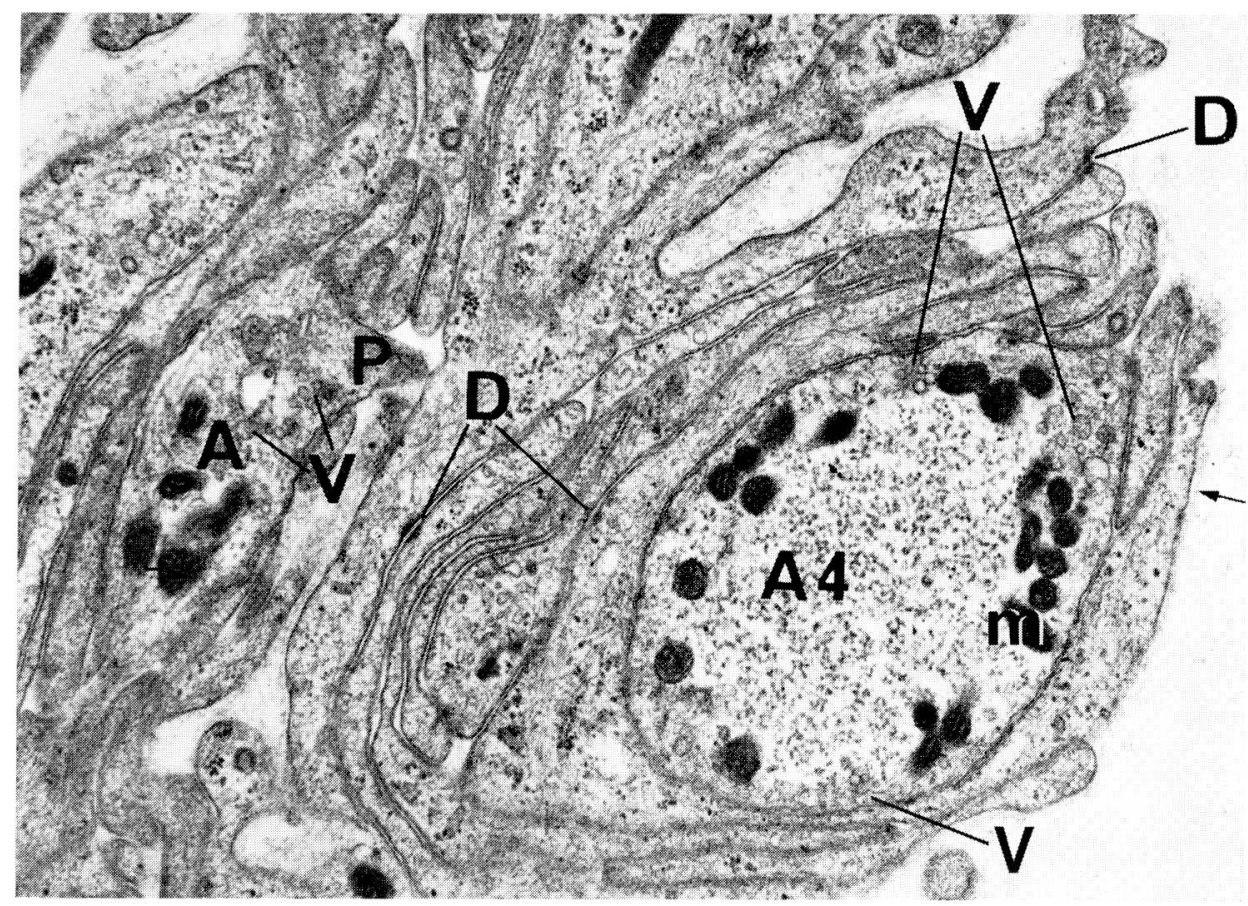

Fig. 6. Higher magnification of the terminal swelling of the axon terminal (A4) shown in Figure 2. The terminal swelling contains peripherally located spherical mitochondria $(m)$ and glycogen particles. The arrow indicates the basal lamina covering the outermost lamellae. $V$ cluster of clear and granular vesicles, $D$ desmosome-like structures, $P$ fingerlike protrusion of the axon terminal $(A) . \quad \times 21,600$ 


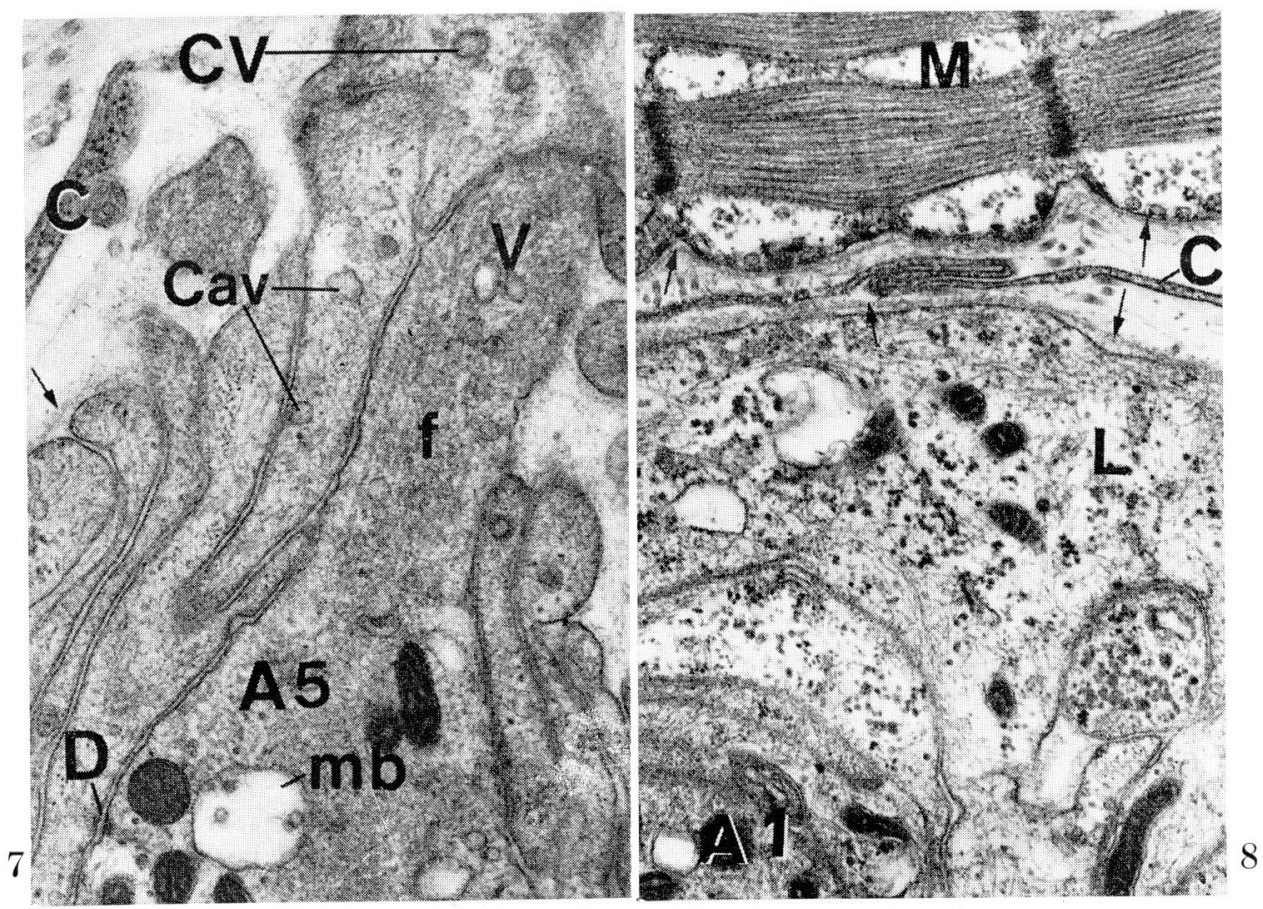

Fig. 7. A finger-like protrusion projecting from a terminal varicosity of the axon (A5) shown in Figure 2. The protrusion contains axillary running microfilaments $(f)$ and clear vesicles $(V)$. CV coated vesicles, Cav caveolae of lamellae, $D$ desmosome-like structure, $m b$ multivesicular body, $C$ capsule, arrow : basal lamina. $\times 32,000$

Fig. 8. Micrograph showing a thin cytoplasmic process $(C)$ of a capsular cell lying between the striated muscle fiber $(M)$ and the corpuscle (see Figure 3). Basal lamina (arrow) is observed on the surface of the lamellar cell $(L)$ and muscle fiber, but not on the capsular cell. A1 axon terminal shown in Figure 2. $\times 23,000$

Golgi apparatus, well-developed rough endoplasmic reticulum, glycogen particles, myeline-figure bodies and microfilaments were noted in the lamellar cell body. The inner lamellae contained only filamentous materials and free ribosomes. The basal lamina was distinct on the outer surface of the lamellar cell bodies. Between the individual lamellae the basal lamina was generally absent, and collagen fibrils were not observed. The individual lamellae were separated by gaps of approximately $250 \mathrm{~A}$ in width. Desmosome-like structures were sometimes found between the lamellae (Fig. 6). Caveolae and coated vesicles were not prominent in the lamellae.

The lamellated corpuscle was surrounded by an incomplete sheath or a capsule consisting of thin cellular processes. Such cellular processes had a higher electron density than the lamellae. Cell organelles were scanty (Fig. 2). Even where the corpuscle was located very close to the striated muscle fibers of the tunica media, the thin cellular process was interposed between the corpuscle and the muscle fibers (Fig. 8). Capsular thin cellular processes lacked a distinct basal lamina.

\section{DISCUSSION}

A previous study by means of silver impregnation showed that Meissner-like corpuscles 


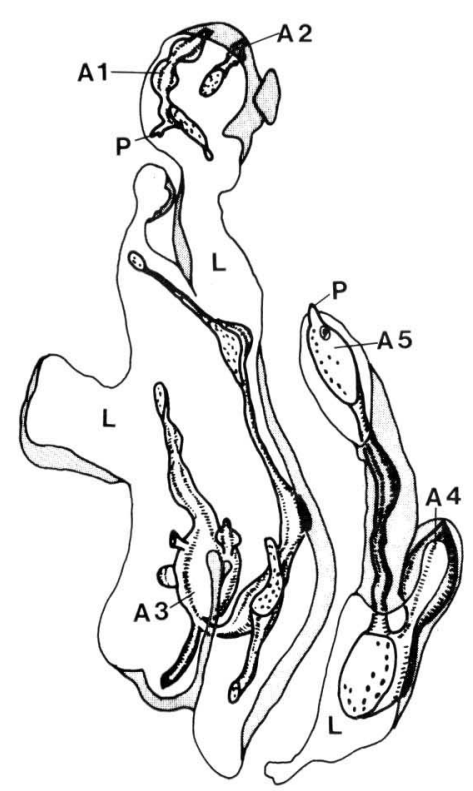

Fig. 9. Schematic drawing of threedimensionally reconstructed axon terminals (A1-5 shown in previous figures). These arborize and form varicosities within the corpuscle. $L$ lamellae surrounding axon terminals, $P$ finger-like protrusions.
(Nervenknäuel) occurred in the tunica media and tunica externa of the lymph hearts of turtles (Clemmys and Geoclemys) (Iто, 1944). Two types of Meissner-like corpuscles have been described so far: "simple small" (60 $\mu \mathrm{m}$ in length and $20 \mu \mathrm{m}$ in width) and "complex large" (100 $\mu \mathrm{m}$ in length and $60 \mu \mathrm{m}$ in width) corpuscles. The former type receives two to three myelinated nerve fibers. ITo (1944) observed branchings and nodular dilatations of axon terminals in the corpuscles.

Recently, SATOH and Nitatori (1980) found in the tunica externa of the Pseudemys lymph heart the occurrence of Meissner-like corpuscles which corresponded in structure to the "simple small corpuscle" of Iто (1944). The three-dimensional reconstruction of their fine structure performed in this study revealed 1) the arborizations and varicositylike dilatations of axon terminals within the corpuscle, 2) densely packed lamellae which surrounded the axon terminals without intervening basal lamina or collagen fibrils, 3) relatively few caveolae on the lamellae and 4) an incomplete capsule of thin cellular processes. It remained unclear in this study how many nerve fibers enter the corpuscle of the Pseudemys lymph heart.

Until now swellings of the receptor axons have been observed only at the terminal tip regions in the lamellated receptors of frog skin (DürING and SEILER, 1974), Herbst corpuscles (Andersen and NAfstad,

1968; Halata, 1971; Saxod, 1978; Chouchkov, 1978), Meissner corpuscles (Ide, 1976), Krause simple Endkolben, Pacinian and Golgi-Mazzoni corpuscles (CHOUchKov, 1978). On the other hand varicosity-like expansions of axon terminals within the corpuscle have been observed only in the lamellated mechanoreceptors of reptilian skin (DüRING, 1973). It may be considered that the varicosity-like dilatations of the axon terminals represent a characteristic feature of lamellated corpuscles in lower vertebrates. Arborization of the axon terminal within the corpuscles seems to occur more generally in sensory corpuscles such as Meissner corpuscle (IDE, 1976), genital and Golgi-Mazzoni corpuscles (Halata, 1975; ChouchKov, 1978).

Densely packed lamellae surrounding the axon terminals and the lack of basal lamina and collagen fibrils interposed between the lamellae have also been observed in the lamellated cutaneous mechanoreceptor of reptiles (DüRING, 1973, 1974). Intervening basal lamina or collagen fibrils between the individual lamellae have been observed in Meissner corpuscles (IDE, 1976), Krause simple Endkolben, Pacinian corpuscles (Chouchkov, 1978), genital end bulbs (Munger, 1971), and lamellated receptors of frog skin (Düring and SEILER, 1974). It has been reported that the interlamellar space of the Herbst corpuscle contains collagen fibrils, but not basal lamina (ANDERSEN and NAFSTAD, 1968; SAXOD, 1978). The lamellar cells in the mechanoreceptors described above were thought to have been derived from the Schwann cell (Halata, 1975; IdE, 1977; Saxod, 1978). 
The lack of basal lamina and the incompleteness of the capsule of the lamellated corpuscle in turtle lymph heart coincide with the findings in the Meissner corpuscle (HALATA, 1975; IdE, 1976) and the lamellated nerve endings in reptilian skin (DÜRING, 1973, 1974). In the present study it is uncertain whether the capsule is continuous with the perineurium.

The lamellated corpuscles as described above have been considered to be mechanoreceptors (probably pressoreceptors in this case) which have rapidly-adapting characteristics (Munger, 1971; Düring and SeIler, 1974; Chouchkov, 1978; Saxod, 1978). Although physiological details of the pressoreceptor of a reptilian lymph heart have not been studied, the receptor seems to contribute to the control of the lymph heart activity.

It has been reported that amphibian lymph hearts, which are better developed than reptilian ones, have no corpuscular nerve endings in the heart wall. This fact might obscure the importance of the corpuscular afferent nerves on the lymph heart function. However, the presence of a relatively large number of unmyelinated nerve fibers in the amphibian lymph heart wall (SATOH and NitATORI, 1980) might indicate that at least some afferent nerve regulations are present in amphibian lymph hearts.

Acknowledgment. Thanks are due to Mr. K. KumagaI for skillful technical assistance.

\section{REFERENCES}

Andersen, A. E. and P. H. J. Nafstad : An electron microscopic investigation of the sensory organs in the hard palate region of the hen (Gallus domesticus). Z. Zellforsch. 91: 391-401 (1968).

Chouchkov, Ch.: Cutaneous receptors. Adv. Anat. Embryol. Cell Biol. 54: 5-61 (1978).

Düring, M. v.: The ultrastructure of lamellated mechanoreceptors in the skin of reptiles. Z. Anat. Entw.-Gesch. 143: 81-94 (1973).

- : The radiant heat receptor and other tissue receptors in the scales of the upper jaw of $B o a$ constrictor. Z. Anat. Entw.-Gesch. 145: 299-319 (1974).

Düring, M. v. and W. Seiler : The fine structure of lamellated receptors in the skin of Rana esculenta. Z. Anat. Entw.-Gesch. 144: 165-172 (1974).

Halata, Z.: Die Ultrastruktur der Lamellenkörperchen bei Wasservögeln (Herbstsche Endigungen). Acta anat. 80: 362-376 (1971).

: The mechanoreceptors of the mammalian skin. Ultrastructure and morphological classification. Adv. Anat. Embryol. Cell Biol. 50: 7-75 (1975).

Ide, C.: The fine structure of the digital corpuscle of the mouse toe pad, with special reference to nerve fibers. Amer. J. Anat. 147: 329-356 (1976).

: Development of Meissner corpuscle of mouse toe pad. Anat. Rec. 188: 49-68 (1977).

Ito, M.: Die nervöse Versorgung des Lymphgefäßsystems. Jap. J. med. Sci. I. Anat. XI: 149-189 (1944).

Kampmeier, O. F.: Evolution and comparative morphology of the lymphatic system. Thomas, Springfield, Illinois, 1969.

Kawaguti, S.: Electron microscopic study on the cross striated muscle in the frog lymph heart. Biol. J. Okayama Univ. 13: 13-22 (1967).

Lindner, E. and G. Schaumburg: Zytoplasmatische Filamente in den quergestreiften Muskelzellen des kaudalen Lymphherzens von Rana temporaria L. Z. Zellforsch. 84: 549-562 (1968).

Munger, B. L.: Patterns of organization of peripheral sensory receptors. In: (ed. by) W. R. Loewenstein: Handbook of sensory physiology. Springer-Verlag, Berlin, 1971 (Vol. 1, p. 523$556)$. 
Rumyantsev, P. P. and I. A. Shmantzar: Ultrastructure of muscle fibres of the frog lymph heart. (Russian text with English summary). Tsitologiya 9: 1129-1136 (1967).

Satoh, Y. and T. Nitatori : On the fine structure of lymph hearts in amphibia and reptiles. In: (ed. by) G. H. Bourne: Hearts and heart-like organs. Academic Press, New York, 1980 (Vol. 1, p. 149-169).

Saxod, R.: Development of cutaneous sensory receptors in birds. In: (ed. by) M. Jacobson: Handbook of sensory physiology. Springer-Verlag, Berlin, 1978 (Vol. 9, p. 337-417).

Schipp, R. and R. Flindt : Zur Feinstruktur und Innervation der Lymphherzmuskulatur der Amphibien (Rana temporaria). Z. Anat. Entw.-Gesch. 127: 232-253 (1968).

佐藤洋一

空078-11 旭川市西神楽 4 線 5 号 3-11

旭川医科大学

解剖学第一講座
Dr. Yoh-ichi SatoH

Department of Anatomy

Asahikawa Medical College

3-11 Nishikagura, 4-sen 5-go

Asahikawa, 078-11 Japan 